\title{
Adding distiller's grains and molasses on fermentation quality of rice straw silages
}

\author{
Adição de melaço na qualidade de fermentação de silagem de palha de arroz
}

\author{
XianJun Yuan ${ }^{I}$ ZhiHao Dong ${ }^{I}$ Seare Tajebe Desta ${ }^{I}$ AiYou Wen ${ }^{\text {II }}$ \\ Xiaoxuan Zhu ${ }^{I}$ Ting Rong ${ }^{I}$ Tao Shao ${ }^{{ }^{*}}$
}

\section{ABSTRACT}

Ensilage is a simple and low-cost strategy to enable long term preservation and environmentally friendly utilization of agricultural by-products, such as straws and distiller's grains (DG) for ruminants. Effect of mixing different proportions of $D G$ and rice straw (i.e. 0, 10, 20 or 30\% of DG) with or without $5 \%$ molasses addition on fermentation and chemical variables of silages was evaluated. The study was conducted as a randomized blocks design in a $4 \times 2$ factorial arrangement, with three replications, using laboratory silos of $1 L$ capacity $(n=24)$. Despite a significant interaction $(P<0.01)$ between $D G$ and molasses addition was observed for most variables, in general the increased addition of $D G$ linearly decreased the $p H$ value, acetic acid (AA), butyric acid $(B A)$ and ammonia $N$ concentration $(P<0.01)$, and increased the lactic acid $(L A)$ concentration $(P<0.01)$. Exception was the propionic acid concentration which linearly decreased without molasses addition and linearly increased with molasses addition at increased proportion of $D G(P<0.01)$. In both silages with or without molasses the addition of $D G$ increased the dry matter, water soluble carbohydrates and crude protein $(P<0.01)$ and decreased the NDF content $(P<0.01)$. Based on the perspective of maximum utilization of rice straw, the mixture of $10 \%$ of $D G$ associated to 5\% molasses at ensilage process is recommended.

Key words: Distiller's grains, fermentation quality, molasses, rice straw, silage.

\section{RESUMO}

Ensilagem é uma estratégia simples e de baixo custo que habilita a preservação de sub-produtos agrícolas por longo tempo e com mínimo impacto ambiental, tal como a preservação de palha de arroz e resíduos da destilação de grãos (DG) para uso na alimentação de ruminantes. $O$ objetivo deste estudo foi avaliar o efeito de incluir diferentes proporções de DG e palha de arroz (i.e. 0, 10, 20 or $30 \%$ of DG) com ou sem inclusão de $5 \%$ de melaço sobre variáveis da fermentação e composição química do material ensilado. O estudo foi conduzido em blocos casualizados em um esquema fatorial $4 \times 2$, com três repetições, utilizando mini-silos de $1 \mathrm{~L}$ de capacidade $(n=24)$. Embora a interação entre $D G$ e melaço foi significativa $(P<0,01)$ para a maior parte das variáveis, em geral a adição de $D G$ diminuiu linearmente o $\mathrm{pH}$ e as concentrações de ácido acético, ácido butírico e amônia $(P<0,01)$, e aumentou linearmente a concentração de ácido láctico $(P<0,01)$. Exceção foi a concentração de ácido propiônico que diminuiu linearmente sem a adição de melaço enquanto aumentou linearmente com a adição de melaço, à incrementados níveis de inclusão de $D G(P<0,01)$. Em ambos casos, com ou sem adição de melaço, a adição de DG aumentou linearmente o teor de matéria seca, de carboidratos solúveis em água e de proteína bruta, e diminuiu o teor de fibra em detergente neutro do material ensilado the NDF content $(P<0,01)$. Baseado na perspectiva de máxima utilização de palha da arroz, recomenda-se a mistura de $10 \%$ de DG associado com $5 \%$ de melaço no processo de ensilagem.

Palavras-chave: Destilação de grãos, a qualidade de fermentação, melaço, palha de arroz, silagem.

\section{INTRODUCTION}

Rice is one of the most important crops in the world, and the annual production of rice straws is more than 192 million tons in China (LI et al., 2010). Most of rice straw is incinerated or disposed as compost, which causes resources wasting and environmental pollution. In the other side, the shortage of feedstuffs during winter has become a limiting factor for the sustainable livestock development in China. An alternative

\footnotetext{
Institute of Ensiling and Processing of Grass, Nanjing Agricultural University, Weigang 1, Nanjing, 210095, China. E-mail: shaotaola@163.com. ${ }^{*}$ Corresponding author.

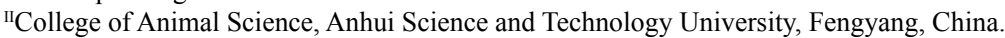
Received 06.12.15 Approved 06.03.16 Returned by the author 10.06.16
} CR-2015-0851.R5 
to solve pollution from straws is to use them as ruminant feed.

Drinking white spirit generates huge amounts of distillers' grains (DG) as an industrial waste, which is disposed in open areas and often caused environmental problems. Distillers' grains are characterized by high crude protein, digestible fiber, ether extract and minerals, and can be used as a feed for lactating cows (PEREIRA et al., 1998; DHIMAN et al., 2003).

In China, how to rationally use these industrial and agricultural by-products has caused an increasing concern. Previous studies reported that ensiling wet brewers' grains (by-product very similar to distiller's grains) with drier feedstuffs resulted in higher digestibility and aerobic stability compared with wet brewers' grains ensiled alone (NISHINO et al., 2003; WANG \& NISHINO, 2008; ANDERSON et al., 2009). It was also reported that the adding of wet hulless-barley distillers' grains to a mixture of oat straw and tall fescue could improve the fermentation and nutritive quality of straw-grass silage in Tibet (YUAN et al., 2013).

Due to the low water soluble carbohydrates (WSC) content in straw, tremendous efforts have been made to improve fermentation quality and nutritive value of straw silage by supplying fermentation substrate directly or indirectly (LI et al., 2010, ZHANG et al., 2010). Molasses has been proven to be an effective silage additive by promoting lactic acid bacteria fermentation, reducing silage $\mathrm{pH}$, discouraging clostridia fermentation and proteolysis, and generally decreasing organic matter losses when applied to crops with low water soluble carbohydrates (WSC) (BOLSEN et al., 1996). However, the information on the utilization of DG and molasses to improve fermentation quality of rice straw silages is lacking.

The objective of this study was to assess the effects of adding distiller's grains and molasses to rice straw on silage fermentation.

\section{MATERIALS AND METHODS}

Experimental design and silage making

A $2 \times 4$ factorial arrangement (4 distillers' grains ratios, with or without molasses) in a randomized blocks design was used as research design. Rice straw and distiller's grains mixtures (DG) were performed at ratios of 100: 0, 90:10, 80:20 and 70:30\% on the fresh basis, while molasses were added at 0 or $5 \%$ of mixtures. Mixtures $(580 \mathrm{~g})$ were well mixed to uniform distribution of each ingredient and packed into a plastic laboratory silo (1-L capacity), and sealed with a screw top. Silos were kept at room temperature and opened after 30 days of ensiling. Three replicates per treatment were performed.

Rice was cultivated and harvested from the experimental plot at Nanjing Agricultural University $\left(32^{\circ} 01^{\prime} 19^{\prime \prime} \mathrm{N}, 118^{\circ} 51^{\prime} 08^{\prime \prime}\right.$ E, elevation $25 \mathrm{~m})$, Jiangsu, China. Crop was mowed by hand at cutting height of $15 \mathrm{~cm}$, and rice straw was the residue remaining after grain harvested and chopped to the length of 2 to $3 \mathrm{~cm}$ with manual forage chopper and immediately collected for silage making. Distiller' grains was obtained from a commercial liquor factory (Rong Liquor Wine Co., Ltd., Zhengjiang, Jiangsu, China) in the morning and ensiled with rice straw the same day in the afternoon. Molasses was an industrial by-product and obtained from a private company (JiaFurui Biological Technology Co., Ltd., Nanjing, Jiangsu, China). Chemical compositions of materials before ensiling are presented in table 1.

Chemical analyses

At sampling, each fresh material or silages were put into an ethanol-disinfected plastic container and mixed uniformly. Each sample was dried in a forced-draft oven at $65^{\circ} \mathrm{C}$ to constant weight, and then ground to pass a $1 \mathrm{~mm}$ screen in a laboratory knife mill (FW100, Taisite Instrument Co., Ltd., Tianjin, China). The

Table1 - Chemical compositions of rice straw, distiller's grains and molasses before ensiling.

\begin{tabular}{lcc}
\hline Item $^{1}$ & Rice straw & Distiller's grains \\
\hline Dry matter $\left(\mathrm{g} \mathrm{kg}^{-1} \mathrm{FW}\right)$ & 317.91 & 339.06 \\
Crude protein $\left(\mathrm{g} \mathrm{kg}^{-1} \mathrm{DM}\right)$ & 54.16 & 186.42 \\
Water soluble carbohydrates $\left(\mathrm{g} \mathrm{kg}^{-1} \mathrm{DM}\right)$ & 15.78 & 42.14 \\
Neutral detergent fiber $\left(\mathrm{g} \mathrm{kg}^{-1} \mathrm{DM}\right)$ & 655.67 & 565.81 \\
Acid detergent fiber $\left(\mathrm{g} \mathrm{kg}^{-1} \mathrm{DM}\right)$ & 409.52 & 502.02 \\
\hline
\end{tabular}

${ }^{1} \mathrm{DM}$, dry matter; FW, fresh weight. 
dried and ground samples were used for chemical analysis. Ground samples were analyzed for dry matter (DM) by drying at $105^{\circ} \mathrm{C}$ f or $24 \mathrm{~h}$. Total $\mathrm{N}$ (TN) was determined by Kjeldahl (Kjeltec 8400 , FOSS, Sweden), and crude protein (CP) content was calculated as $\mathrm{TN} \times 6.25$. Content of WSC was analyzed by colorimetry after reaction with anthrone reagent (THOMAS, 1977).

Neutral detergent fibre (NDF) and acid detergent fibre (ADF) were analyzed according to the procedures of Van SOEST et al. (1991), using heat stable amylase and sodium sulphite and the results were expressed on DM basis including residual ash.

Silage $\mathrm{pH}$, lactic acid (LA), ammonia nitrogen (AN), and volatile fatty acids (VFAs) were analyzed using distilled water extracts of silages. A sub-sample of silages $(35 \mathrm{~g})$ was macerated with $70 \mathrm{~g}$ distilled water and stored at $4^{\circ} \mathrm{C}$ in the refrigerator at $4^{\circ} \mathrm{C}$ for $24 \mathrm{~h}$, and then the extracts were filtered through two layers of cheese cloth and filter paper. The $\mathrm{pH}$ of extracts was measured with a glass electrode $\mathrm{pH}$ meter (HANNA $\mathrm{pH}$ 211, Hanna Instruments Italia Srl, Padova, Italy). The concentration of LA was determined by colorimetric procedure as reported by BARKER \& SUMMERSON (1941). Concentrations of VFAs (including acetic acid, propionic acid and butyric acid) were determined using gas chromatography equipped with a flame ionization detection (FID) system (Shimadzu GC-17A, with $30 \mathrm{~m} \times 0.25 \mathrm{~mm}$ [diameter of film: $0.25 \mu \mathrm{m}$ ] capillary column, acidmodified poly [ethylene glycol] phase, GADA24107, Sigma-Aldrich Co.; conditions: column temperature $125^{\circ} \mathrm{C}$, injection temperature $220^{\circ} \mathrm{C}$ ). Ammonia nitrogen (AN) was determined according to the method of phenol-hypochlorite reaction (BRODERICK \& KANG, 1980).

Statistical analyses

Silage fermentation and chemical composition data were analyzed in a randomized block design using the PROC GLM procedure of SAS 9.3 (SAS Inst. Inc., Cary, NC) with a model: $\mathrm{Y}_{\mathrm{ijk}}=\mu+\alpha_{\mathrm{i}}+\beta_{\mathrm{j}}+\alpha \beta_{\mathrm{ij}}+\mathrm{e}_{\mathrm{ijk}}$, where $\mu$ is the general mean; $\alpha_{i}$ is the DG effect $(i=0,10,20$ or $30 \%), \beta_{j}$ is the molasses effect ( $\mathrm{j}=$ with or without), $\alpha \beta_{\mathrm{ij}}$ is the $\mathrm{DG}$ $\times$ molasses interaction and $e_{i j k}$ is the residual error, for each effect three replications were used. Sums of squares for treatment effects were further separated using orthogonal contrasts into single-degree-offreedom comparisons to test for the significance of linear and quadratic components of response to incremental ratios of DG in the mixed silages.

\section{RESULTS}

As shown in table 2 and table 3, the addition of molasses significantly influenced all of the fermentation parameters and silage chemical composition of $(\mathrm{P}<0.01)$. Among silages without molasses, the addition of distiller's grains significantly decreased $\mathrm{pH}$ value (L, $\mathrm{Q}, \mathrm{P}<0.01)$, and affected $\mathrm{LA}$, acetic (AA), and butyric (AA) acid concentrations (L, $\mathrm{Q}, \mathrm{P}<0.01$ ), while ammonia $\mathrm{N}$ linearly decreased with increasing rates of $\mathrm{DG}(\mathrm{L}, \mathrm{P}<0.01)$. The addition of distiller's grains significantly increased WSC and CP concentrations ( $\mathrm{L}, \mathrm{Q}, \mathrm{P}<0.01)$. The DM contents linearly increased $(\mathrm{L}, \mathrm{P}<0.01)$, while NDF contents linearly decreased with the increasing rates of distiller's grains $(\mathrm{L}, \mathrm{P}<0.01)$.

The addition of $\mathrm{M}$ significantly affected WSC and CP contents $(\mathrm{P}<0.01)$, and all of the fermentation parameters of silages with different levels of DG, except silage $\mathrm{pH}(\mathrm{P}=0.02)$. For silages with molasses, the addition of distiller's grains significantly affected LA/AA, and LA, AA, BA and ammonia $\mathrm{N}(\mathrm{L}, \mathrm{Q} \mathrm{P}<0.01)$. The $\mathrm{pH}$ value linearly decreased $(\mathrm{L}, \mathrm{P}<0.01)$, while $\mathrm{PA}$ concentration linearly increased with the increasing rates of $D G$ (L, $\mathrm{P}<0.01)$. The addition of distiller's grains linearly increased DM, WSC, and CP contents $(\mathrm{L}, \mathrm{P}<0.01)$, while reduced NDF contents $(\mathrm{L}, \mathrm{P}<0.01)$.

\section{DISCUSSION}

The WSC content of rice straw and DG were lower than the recommended value of 60 and $80 \mathrm{~g} \mathrm{~kg}^{-1} \mathrm{DM}$ for successful preservation of crops according to Woolford (1984). In the present study, the addition of molasses alone enhanced lactic acid fermentation, declining $\mathrm{pH}$. The rapid and vigorous LA accumulation could depress the proteolysis and activity of clostridia or other undesirable bacteria (NISHINO et al., 2012). This is consistent with the lower AA, PA, BA and ammonia $\mathrm{N}$ concentration observed in the silages with molasses in the study. Compared to rice straw silage, molasses addition alone significantly decreased NDF and ADF, probably due to acid hydrolysis of cell walls carbohydrates resultant from reduction in silage $\mathrm{pH}$ by lactic acid fermentation (AKSU et al., 2006; JONES et al., 1992).

In the present experiment, distiller's grains addition alone improved the fermentation quality even at the lowest level of inclusion, revealing lower $\mathrm{pH}$ and BA concentration, and higher LA/AA, WSC and LA concentration. Plant respiration and aerobic 
Table 2 - Fermentation quality of rice straw silages treated with distiller's grains or/and molasses.

\begin{tabular}{|c|c|c|c|c|c|c|c|c|c|c|c|}
\hline \multirow[t]{2}{*}{ Parameter $^{1}$} & \multirow[t]{2}{*}{ Molasses } & \multirow[t]{2}{*}{$0 \% \mathrm{DG}$} & \multirow[t]{2}{*}{$10 \% \mathrm{DG}$} & \multirow[t]{2}{*}{$20 \%$ DG } & \multirow[t]{2}{*}{$30 \% \mathrm{DG}$} & \multicolumn{2}{|c|}{$\begin{array}{l}\text { P value for contrasts of } \\
\text { DG levels }{ }^{2}\end{array}$} & \multirow[t]{2}{*}{$\mathrm{SEM}^{3}$} & \multicolumn{3}{|c|}{------------P value ${ }^{4}------------$} \\
\hline & & & & & & $\mathrm{L}$ & Q & & $\mathrm{M}$ & DG & $\mathrm{M} \times \mathrm{DG}$ \\
\hline \multirow{2}{*}{$\mathrm{pH}$ value } & Without & 4.84 & 4.10 & 3.86 & 3.75 & $<0.01$ & $<0.01$ & \multirow{2}{*}{0.076} & \multirow{2}{*}{$<0.01$} & \multirow{2}{*}{$<0.01$} & \multirow{2}{*}{0.02} \\
\hline & With & 4.06 & 3.67 & 3.60 & 3.59 & $<0.01$ & 0.07 & & & & \\
\hline \multirow{2}{*}{ LA } & Without & 4.45 & 39.4 & 48.8 & 69.9 & $<0.01$ & $<0.01$ & \multirow{2}{*}{5.01} & \multirow{2}{*}{$<0.01$} & \multirow{2}{*}{$<0.01$} & \multirow{2}{*}{$<0.01$} \\
\hline & With & 44.4 & 86.1 & 89.2 & 86.6 & $<0.01$ & $<0.01$ & & & & \\
\hline \multirow{2}{*}{ AA } & Without & 11.3 & 4.22 & 12.4 & 9.49 & $<0.01$ & $<0.01$ & \multirow{2}{*}{0.440} & \multirow{2}{*}{$<0.01$} & \multirow{2}{*}{$<0.01$} & \multirow{2}{*}{$<0.01$} \\
\hline & With & 6.61 & 10.1 & 9.51 & 10.0 & $<0.01$ & $<0.01$ & & & & \\
\hline \multirow{2}{*}{ LA/AA } & Without & 0.363 & 8.61 & 5.62 & 7.47 & $<0.01$ & $<0.01$ & \multirow{2}{*}{0.506} & \multirow{2}{*}{$<0.01$} & \multirow{2}{*}{$<0.01$} & \multirow{2}{*}{$<0.01$} \\
\hline & With & 6.88 & 9.09 & 9.60 & 8.77 & $<0.01$ & $<0.01$ & & & & \\
\hline \multirow{2}{*}{ PA } & Without & 0.635 & 0.306 & 0.323 & 0.244 & $<0.01$ & $<0.01$ & \multirow{2}{*}{0.028} & \multirow{2}{*}{$<0.01$} & \multirow{2}{*}{$<0.01$} & \multirow{2}{*}{$<0.01$} \\
\hline & With & 0.110 & 0.151 & 0.146 & 0.237 & $<0.01$ & 0.24 & & & & \\
\hline PA & Without & 21.2 & 7.16 & 2.77 & 1.78 & $<0.01$ & $<0.01$ & 117 & $<\Omega \Omega 1$ & $<0 \Omega 1$ & $<0 \Omega 1$ \\
\hline DA & With & 8.75 & 1.15 & 0.72 & 1.28 & $<0.01$ & $<0.01$ & 1.17 & $<0.01$ & $<0.01$ & $<0.01$ \\
\hline VFAs & Without & 33.2 & 11.7 & 15.4 & 11.5 & $<0.01$ & $<0.01$ & 127 & $<0 \cap 01$ & $<001$ & $<001$ \\
\hline VFAS & With & 15.5 & 11.4 & 10.4 & 11.5 & $<0.01$ & $<0.01$ & 1.21 & $<0.01$ & $<0.01$ & $<0.01$ \\
\hline & Without & 83.9 & 71.8 & 69.7 & 62.9 & $<0.01$ & 0.02 & 1.96 & $<0.01$ & $<0.01$ & $<0.01$ \\
\hline AN & With & 55.6 & 51.0 & 50.1 & 61.7 & $<0.01$ & $<0.01$ & & & & \\
\hline
\end{tabular}

${ }^{1} \mathrm{LA}=$ lactic acid $\left(\mathrm{g} \mathrm{kg}^{-1} \mathrm{DM}\right) ; \mathrm{AA}=$ acetic acid $\left(\mathrm{g} \mathrm{kg}^{-1} \mathrm{DM}\right) ; \mathrm{PA}=$ propionic acid $\left(\mathrm{g} \mathrm{kg}^{-1} \mathrm{DM}\right) ; \mathrm{BA}=\mathrm{butyric}$ acid $\left(\mathrm{g} \mathrm{kg}{ }^{-1} \mathrm{DM}\right) ; \mathrm{VFAs}=\mathrm{total}$ volatile fatty acids $\left(\mathrm{g} \mathrm{kg}^{-1} \mathrm{DM}\right) ; \mathrm{TN}=$ total $\mathrm{N} ; \mathrm{AN}=\operatorname{ammonia} \mathrm{N}\left(\mathrm{g} \mathrm{kg}^{-1} \mathrm{TN}\right)$.

${ }^{2} \mathrm{~L}=$ linear effect; $\mathrm{Q}=$ quadratic effect.

${ }^{3} \mathrm{SEM}=$ standard error of means.

${ }^{4} \mathrm{M}=$ molasses main effect; $\mathrm{DG}=$ distiller's grains main effect; $\mathrm{M} \times \mathrm{DG}$, interaction between molasses and distiller's grains.

bacteria dominated the initial stage of ensiling due to poor compaction for rice straw silage resulted in the fermentable substrates and nutrient loss, while residual ethanol contained in distiller's grain possessed the ability to depress the growth of clostridia and other undesirable aerobic bacteria (OHBA et al., 2002). Higher inclusion rates of distiller's grains $(20 \%$ and $30 \% \mathrm{DG}$ ) further declined $\mathrm{pH}$, ammonia $\mathrm{N}$ and BA concentration and increased LA/AA, WSC and LA concentration, which was consistent with our previous results (YUAN et al., 2012).

There were significantly higher CP and slightly lower NDF content in silages, which included distiller's grains. When compared with rice straw alone, these were consistent with the properties of distiller's grains before ensiling, which showed higher $\mathrm{CP}$ and lower NDF and ADF than rice straw.

Distiller's grains plus molasses further increased LA concentration and decreased BA and AN concentrations as compared with silages when included with distiller's grains alone, suggesting that the combination of molasses and DG had particular benefit when applied to low WSC materials. Although distiller's grains alone addition probably inhibited the activity of undesirable aerobic bacteria (OHBA et al., 2002), mixture of rice straw and distiller's grains could not provide enough fermentable substrates for LA fermentation to decrease the final $\mathrm{pH}$ value. Whereas distiller's grains combined with molasses stimulated the activity of $\mathrm{LAB}$, enhanced rapid LA accumulation to cause fast drop in $\mathrm{pH}$, and further inhibited the proteolysis and activity of undesirable bacteria.

Combined addition of distiller's grains and molasses further improved the fermentation quality compared to silage with molasses alone; however, there were no great differences in $\mathrm{pH}$, 
Table 3 - Chemical compositions of rice straw silages treated with distiller's grains or/and molasses.

\begin{tabular}{|c|c|c|c|c|c|c|c|c|c|c|c|}
\hline \multirow[t]{2}{*}{ Parameter $^{1}$} & \multirow[t]{2}{*}{ Molasses } & \multirow[t]{2}{*}{$0 \% \mathrm{DG}$} & \multirow[t]{2}{*}{$10 \% \mathrm{DG}$} & \multirow[t]{2}{*}{$20 \% \mathrm{DG}$} & \multirow[t]{2}{*}{$30 \% \mathrm{DG}$} & \multicolumn{2}{|c|}{$\begin{array}{l}\text { P value for contrasts of } \\
\text { DG levels }\end{array}$} & \multirow[t]{2}{*}{ SEM $^{3}$} & \multicolumn{3}{|c|}{----------P value } \\
\hline & & & & & & $\mathrm{L}$ & Q & & M & DG & $\mathrm{M} \times \mathrm{DG}$ \\
\hline \multirow{2}{*}{ DM } & Without & 268 & 307 & 321 & 342 & $<0.01$ & 0.04 & \multirow{2}{*}{5.05} & \multirow{2}{*}{$<0.01$} & \multirow{2}{*}{$<0.01$} & \multirow{2}{*}{0.08} \\
\hline & With & 07 & 331 & 343 & 365 & $<0.01$ & 0.71 & & & & \\
\hline \multirow{2}{*}{ WSC } & Without & 8.23 & 8.73 & 10.7 & 19.3 & $<0.01$ & $<0.01$ & \multirow{2}{*}{2.04} & \multirow{2}{*}{$<0.01$} & \multirow{2}{*}{$<0.01$} & \multirow{2}{*}{$<0.01$} \\
\hline & With & 15.2 & 20.8 & 34.6 & 40.9 & $<0.01$ & 0.65 & & & & \\
\hline \multirow{2}{*}{$\mathrm{CP}$} & Without & 56.0 & 64.6 & 85.1 & 77.4 & $<0.01$ & $<0.01$ & \multirow{2}{*}{2.12} & \multirow{2}{*}{$<0.01$} & \multirow{2}{*}{$<0.01$} & \multirow{2}{*}{$<0.01$} \\
\hline & With & 55.3 & 69.5 & 80.1 & 87.0 & $<0.01$ & $<0.01$ & & & & \\
\hline \multirow{2}{*}{ NDF } & Without & 640 & 621 & 597 & 561 & $<0.01$ & 0.38 & \multirow{2}{*}{7.70} & \multirow{2}{*}{$<0.01$} & \multirow{2}{*}{$<0.01$} & \multirow{2}{*}{0.04} \\
\hline & With & 585 & 545 & 521 & 540 & $<0.01$ & 0.02 & & & & \\
\hline \multirow{2}{*}{$\mathrm{ADF}$} & Without & 420 & 412 & 409 & 408 & 0.43 & 0.74 & \multirow{2}{*}{4.58} & \multirow{2}{*}{$<0.01$} & \multirow{2}{*}{0.76} & \multirow{2}{*}{0.37} \\
\hline & With & 373 & 366 & 380 & 391 & 0.09 & 0.31 & & & & \\
\hline
\end{tabular}

${ }^{1} \mathrm{DM}=$ dry matter $\left(\mathrm{g} \mathrm{kg}^{-1} \mathrm{FW}\right) ; \mathrm{WSC}=$ water soluble carbohydrates $\left(\mathrm{g} \mathrm{kg}^{-1} \mathrm{DM}\right) ; \mathrm{CP}=$ crude protein $\left(\mathrm{g} \mathrm{kg}^{-1} \mathrm{DM}\right) ; \mathrm{NDF}=$ neutral detergent fibre $\left(\mathrm{g} \mathrm{kg}^{-1} \mathrm{DM}\right) ; \mathrm{ADF}=$ acid detergent $?$ bre $\left(\mathrm{g} \mathrm{kg}^{-1} \mathrm{DM}\right)$.

${ }^{2} \mathrm{~L}=$ linear effect; $\mathrm{Q}=$ quadratic effect.

${ }^{3} \mathrm{SEM}=$ standard error of means.

${ }^{4} \mathrm{M}=$ molasses main effect; $\mathrm{DG}=$ distiller's grains main effect; $\mathrm{M} \times \mathrm{DG}$, interaction between molasses and distiller's grains .

LA and BA concentrations among combination addition silages. This indicated that $10 \% \mathrm{DG}$ inclusion was adequate and effective in enhancing the LA fermentation and discouraging undesired microorganisms, because no further improvement in fermentation quality was observed with increasing the rate of distiller's grains addition.

Compared to silage with distiller's grains or molasses alone, silages treated with distiller's grains and molasses showed higher DM, residual WSC and CP contents, while lower NDF content, implying synergetic effect of molasses and distiller's grains on improving silages.

\section{CONCLUSION}

Based on the perspective of maximum utilization of rice straw, the mixture of rice straw and distiller's grains at 9:1 associated to $5 \%$ molasses at ensilage was recommended for efficiently utilizing rice straw.

\section{ACKNOWLEDGMENTS}

This research was partially supported supported by independent innovation of agricultural sciences in JiangSu province (CX(15)1003), China National Science Foundation (31402135) and Natural Science Foundation of Jiangsu Province of China (BK20140717).

\section{REFERENCES}

AKSU, T. et al. Effects of formic acid, molasses and inoculant additives on corn silage composition, organic matter digestibility and microbial protein synthesis in sheep. Small Ruminant Research, v.61, n.1, p.29-33, 2006. Avaliable from: $<$ http://www. sciencedirect.com/science/article/pii/S0921448805000271>. Accessed: Jun. 30, 2016. doi:10.1016/j.smallrumres.2004.12.013.

ANDERSON, J.L. et al. Ensiling characteristics of wet distillers grains mixed with soybean hulls and evaluation of the feeding value for growing Holstein heifers. Journal of AnimalScience, v.87, n.6, p. 21132123, 2009. Avaliable from: $<$ https://www.animalsciencepublications. org/publications/jas/abstracts/87/6/0872113>. Accessed: Jun. 30, 2016. doi:10.2527/jas.2008-1607.

BARKER SB; SUMMERSON, W.H. The colorimetric determination of lactic acid in biological material. Journal of Biological Chemistry, v.138, 535-554, 1941.

BOLSEN, K.K. et al. Silage fermentation and silage additives. Review. Asian-Australasian Journal of Animal Sciences, v.9, n.5, p.483-493, 1996. Avaliable from: <http://ajas.info/journal/ view.php?doi=10.5713/ajas.1996.483>. Accessed: Jun. 30, 2016. doi:10.5713/ajas.1996.483.

BRODERICK, G.A.; KANG, J.H. Automated simultaneous determination of ammonia and total amino acids in ruminal fluid and in vitro media. Journal of Dairy Science, v.63, n.1, p.64-75, 1980. Avaliable from: <http://www.sciencedirect.com/science/ article/pii/S0022030280828888>. Accessed: Jun. 30, 2016. doi:10.3168/jds.S0022-0302(80)82888-8.

DHIMAN, T.R. et al. Production response of lactating cows fed dried versus wet brewers' grain in diets with similar dry matter 
content. Journal of Dairy Science, v.86, n.9, p.2914-2921, 2003. Avaliable from: $<$ http://www.sciencedirect.com/science/article/pii/ S0022030203738880>. Accessed: Jun. 30, 2016. doi:10.3168/jds. S0022-0302(03)73888-0.

LI, J. et al. Improvement of fermentation quality of rice straw silage by application of a bacterial inoculant and glucose. AsianAustralasian Journal of Animal Sciences, v.23, n.7, p.901906, 2010. Avaliable from: <http://www.ajas.info/journal/view. php?number $=22328>$. Accessed: Jun. 30, 2016. doi: 10.5713/ ajas.2010.90403.

NISHINO, N. et al. Evaluation of fermentation and aerobic stability of wet brewers' grains ensiled alone or in combination with various feeds as a total mixed ration. Journal of the Science of Food and Agriculture, v.83, n.6, p.557-563, 2003. Avaliable from: <http://dx.doi.org/10.1002/jsfa.1395>. Accessed: Jun. 30, 2016. doi:10.1002/jsfa.1395.

NISHINO, N. et al. Effects of wilting and molasses addition on fermentation and bacterial community in guinea grass silage. Letters in Applied Microbiology, v.54, n.3, p.175-181, 2012. Avaliable from: <http://dx.doi.org/10.1111/j.1472-765X.2011.03191.x>. Accessed: Jun. 30, 2016. doi: 10.1111/j.1472-765X.2011.03191.x.

OHBA, N. et al. Effect of ethanol addition on ensiling of forage oats and italian ryegrass. Science Bulletin of the Faculty of Agriculture Kyushu University, v.57, 11-15, 2002. Avaliable from: <http:// catalog.lib.kyushu-u.ac.jp/en/recordID/21117?hit $=4 \&$ caller $=x c-$ search $>$. Accessed: Jun. 30, 2016. doi: 10.15017/21117.

PEREIRA, J.C. et al. Rumen degradability and intestinal digestibility of brewers' grains as affected by origin and heat treatment and of barley rootlets. Animal Feed Science and Technology, v.74, n.2, p.107-121, 1998. Avaliable from: <http:// www.sciencedirect.com/science/article/B6T42-3TJC5192/2/238f7d69205d6887f9e1ee5c39e9dfbf $>$. Accessed: Jun. 30, 2016. doi: 10.1016/S0377-8401(98)00168-0.

THOMAS, T.A. An automated procedure for the determination of soluble carbohydrates in herbage. Journal of the Science of
Food and Agriculture, v.28, n.7, p.639-642, 1977. Avaliable from: $<$ http://dx.doi.org/10.1002/jsfa.2740280711>. Accessed: Jun. 30, 2016. doi: 10.1002/jsfa.2740280711.

VAN SOEST, P.J. et al. Methods for dietary fiber, neutral detergent fiber, and nonstarch polysaccharides in relation to animal nutrition. Journal of Dairy Science, v.74, n.10, p.3583-3597, 1991. Avaliable from: $<$ http://www.sciencedirect.com/science/article/pii/ S0022030291785512>. Accessed: Jun. 30, 2016. doi: 10.3168/jds. S0022-0302(91)78551-2.

WANG, F.; NISHINO, N. Effect of aerobic exposure after silo opening on feed intake and digestibility of total mixed ration silage containing wet brewers grains or soybean curd residue. Grassland Science, v.54, n.3, p.164-166, 2008. Avaliable from: <http://dx.doi. org/10.1111/j.1744-697X.2008.00118.x>. Accessed: Jun. 30, 2016. doi: 10.1111/j.1744-697X.2008.00118.X.

WOOLFORD, M.K. The silage fermentation. New York: Marcel Dekker, 1984. 368p.

YUAN, X. et al. Effect of inclusion of grasses and wet hullessbarley distillers' grains on the fermentation and nutritive quality of oat straw- and straw-grass silages in Tibet. Animal Production Science, v.53, n.5, p.419-426, 2013. Avaliable from: $<$ http://www. publish.csiro.au/paper/AN12196>. Accessed: Jun. 30, 2016. doi: 10.1071/AN12196.

YUAN, X.J. et al. Improvement of Fermentation and nutritive quality of straw-grass silage by inclusion of Wet Hulless-barley Distillers' Grains in Tibet. Asian-Australasian Journal of Animal Sciences, v.25, n.4, p.479-485, 2012. Avaliable from: $<$ http://ajas. info/journal/view.php?doi=10.5713/ajas.2011.11435>. Accessed: Jun. 30, 2016. doi: 10.5713/ajas.2011.11435.

ZHANG, J.G. et al. Relationships between the addition rates of cellulase or glucose and silage fermentation at different temperatures. Animal Science Journal, v.81, n.3, p.325-330, 2010. Avaliable from: $<\mathrm{http}$ ://onlinelibrary.wiley.com/doi/10.1111/ j.1740-0929.2010.00745.x/abstract>. Accessed: Jun. 30, 2016. doi: 10.1111/j.1740-0929.2010.00745.x. 